\title{
Colonization of forest clearings and tree-fall gaps in lowland rain forests of Colombia by hemiepiphytic aroids: experimental and transect studies
}

\author{
Ana María Benavides*,1, Jan H. D. Wolf $\dagger$ and Joost F. Duivenvoorden $\dagger$ \\ *Corporación para Investigaciones Biológicas (CIB), Medellín, Colombia \\ †Institute for Biodiversity and Ecosystem Dynamics (IBED), University of Amsterdam, PO Box 94248, 1090 GE Amsterdam, the Netherlands \\ (Received 16 February 2012; revised 15 January 2013; accepted 15 January 2013; first published online 27 February 2013)
}

\begin{abstract}
The contribution of vegetative recruitment by non-tree species to the regeneration of tropical forests in man-made clearings or tree-fall gaps tends to be ignored. In a series of field studies near Amacayacu, Colombian Amazonia, we tested if hemiepiphytic aroids quickly colonize such open habitats through seed dispersal, sprouting plant fragments, or lateral invasion of flagellar aroids from the closed forest nearby. A seed germination experiment applying two soil substrates and three shade levels showed that abundant light reduced the germination success of three Philodendron species. A total of 400 cuttings from five Philodendron species were placed in forest clearings and almost $12 \%$ of these sprouted within 14 wk. Monitoring more than 2000 aroid plants over 14 mo in different habitats showed that recruitment was low $\left(0.3\right.$ plants per $\left.10 \mathrm{~m}^{2}\right)$ compared with initial densities $\left(3.1\right.$ plants per $\left.10 \mathrm{~m}^{2}\right)$. Flagellar aroids grew about 2.5 times faster than non-flagellar aroids. In forest edges they reached a mean apical growth of $98 \mathrm{~cm}$ in 14 mo. However, non-flagellar aroids were five to six times more abundant than flagellar individuals everywhere. It was concluded that hemiepiphytic aroids colonize open habitats mostly through a post-disturbance survival of plants or plant fragments.
\end{abstract}

Key Words: Amacayacu National Park, Amazonia, Araceae, directional growth, flagellar shoot, Philodendron, succession

\section{INTRODUCTION}

In tropical forests, tree-falls, landslides and subsistence agriculture, among others, regularly produce small gaps that offer plants new habitats for colonization and create gradients in light (Chazdon 1986, Denslow 1987, Grubb 1977). Regeneration studies in forest clearings, fallows or tree-fall gaps usually consider trees (Schnitzer et al. 2008) and ignore the contribution of vegetative recruitment (Lasso et al. 2009). Plants may colonize such open habitats through germinating seeds, which are present in a seed bank or arrive by dispersal (Dalling et al. 1998). Colonization may also take place through vegetative recruitment by sprouting roots or stem fragments that survive gap formation (Schnitzer \& Carson 2001) or creeping plants that laterally invade from the adjacent forest (Schnitzer et al. 2008). Creeping recruits are often the first to colonize tree-fall gaps, leading to canopy closure

\footnotetext{
${ }^{1}$ Corresponding author. Email: anamaria.benavides@gmail.com Postal address: Corporación para Investigaciones Biológicas (CIB), Cra. 72 A No 78 B 141, Medellín, Colombia
}

within a few months (Clark et al. 1999, Schnitzer et al. 2000). Many such creeping plants are hemiepiphytes i.e. ground-rooted plants that spend a part of their life cycle as ground-detached epiphytes. In the neotropics, these hemiepiphytes often belong to Araceae (aroids), one of the world's most species-rich and abundant epiphytic families (Bazzaz \& Pickett 1980, Benavides et al. 2006, 2011; Croat 1992, Gentry \& Dodson 1987, Nieder et al. 2000).

Young successional forests in fallows (Benavides et al. 2006) or floodplains (Leimbeck \& Balslev 2001) in the Amazon basin may already contain a large number of species and individuals of hemiepiphytic aroids, especially in comparison to holoepiphytes. The rapid colonization by hemiepiphytic aroids might be related to particular functional traits. In many aroids, creeping stems and descending shoots exhibit abrupt morphological changes by becoming flagellar (Ray 1992). Flagellar shoots (showing internodes that are c. 35 times as long as wide) may have rapid growth and are seen not only as a mechanism to forage for essential resources, but also to multiply and disperse meristems clonally into newly available habitats (Andrade \& Mayo 2000, BalcázarVargas et al. 2012, Ray 1992). 
Our study addressed the hypothesis that hemiepiphytic aroids are well adapted to quickly occupy small, open habitats in forests. We hypothesized that this quick aroid colonization (Benavides et al. 2006, Leimbeck \& Balslev 2001) is mainly by seeds, vegetative reproduction through sprouting fragments of fallen aroids, or invasion through lateral growth of flagellar aroids from the closed forest nearby. Our specific hypotheses were as follows: (1) Abundant light in open habitats enhances aroid seed germination. (2) Aroids reproduce vegetatively by sprouting fragments. (3) In open habitats flagellar aroids are more abundant than non-flagellar aroids whereas in closed forests this difference is less pronounced. (4) Aroids, and especially flagellar aroids, grow faster in open habitats than in closed forests. (5) They also show faster growth in forest edges when occurring closer to open habitats. (6) Finally, they show directional growth towards the open habitat in such conditions.

\section{METHODS}

\section{Study area}

We undertook fieldwork from May 2008 to September 2009 in Amacayacu National Park and adjacent Ticuna territory, located in Colombian Amazonia $\left(3^{\circ} \mathrm{S}, 69^{\circ}-\right.$ $\left.70^{\circ} \mathrm{W}\right)$. The area has a bimodal annual precipitation of $c .3200 \mathrm{~mm}$, with a relatively dry period between June and September. The average annual temperature is c. $26{ }^{\circ} \mathrm{C}$ and the daily average for relative humidity is c. $86 \%$ (Rudas \& Prieto 2005). The area is covered with tropical rain forest (Rudas \& Prieto 2005). In total, 58 epiphytic aroid species were reported in the area (Benavides et al. 2006). Local communities use shifting cultivation for subsistence agriculture. Man-made clearings in the forest to cultivate crops are up to 2 ha in size, generally square or rectangular in shape, and are used for polyculture plantations of crops such as cassava and banana. After approximately $6 \mathrm{y}$, the clearings are abandoned and the forest regenerates (fallows). In this paper, we employ the term 'open habitat' as a generic term that includes recent clearings, fallows and natural tree-fall gaps, with clarification where necessary.

\section{Fieldwork}

Seed germination was studied for three aroid species that were known to fruit abundantly in the region (Philodendron ernestii, P. wittianum and P. fragantissimum). We sowed seeds out of a pooled batch that were collected from at least ten mature fruits of eight individual plants per species. P. ernestii and $P$. wittianum were sown in November 2008 and P. fragrantissimum was sown 2 mo later. Ten seeds were sown in every cell of a 32-cell tray. Half of the cells were filled with a mix of soil samples taken at 0-10 cm depth (after removal of the litter layer) in four mature-forest sites, and the other 16 cells with a similar mix of soil samples from three fallows. Two trays were placed on a table in a clearing under each of three lightexposure regimes (for Philodendron ernestii only one tray per light regime was used). Using shade cloths that blocked $25 \%, 55 \%$ and $85 \%$ of sunlight we varied light exposure. While maintaining the light exposure regime, the position of the trays on the table was changed randomly each week. The germination of all three species ceased after 2 mo. The experiment was conducted in the village of Mocagua $\left(03^{\circ} 48^{\prime} \mathrm{S}, 70^{\circ} 15^{\prime} \mathrm{W}\right)$.

The sprouting capability was studied by placing stem cuttings $c .30 \mathrm{~cm}$ long (middle portion of stems with three nodes) from at least 10 adult plants of five aroid species (80 stem cuttings for each species) in four recent $(<1 \mathrm{y}$ old $)$ clearings under controlled conditions. After placement, sprouting of each cutting was recorded after 6 and 14 wk.

We monitored the recruitment and apical growth of secondary hemiepiphytic aroids during a period of 14 mo (between July 2008 and September 2009). This monitoring was done along 2-m-wide transects of variable length that covered three habitats: open habitats, comprising recent forest clearings and fallows less than $2 \mathrm{y}$ old; forest edges at either side of these open habitats; and mature forests at least $200 \mathrm{~m}$ away from any clearing or fallow. A total of 14 transects were located through the centre of randomly picked clearings or fallows, and continued 15 to $35 \mathrm{~m}$ into the forest edge at either side of these. Eight additional transects of $25 \mathrm{~m}$ length were laid out in mature forests. In total the initial area for monitoring comprised $1760 \mathrm{~m}^{2}$ in open habitats, $1150 \mathrm{~m}^{2}$ in forest edges and $400 \mathrm{~m}^{2}$ in mature forests. Fire destroyed one transect (covering open habitat and adjacent forest edge) after 2 mo. At each transect, we mapped all aroids that were known to have a hemiepiphytic life form, and marked these with plastic tags or aluminium wire, regardless of whether or not they were attached to trees. Since hemiepiphytic aroids do not attain great height on the tree, binocular observations sufficed and no tree climbing was required. For each aroid, we recorded species name and whether the shoots were flagellar (Ray 1992). After initial mapping, we returned every 2 mo to record recruits and their recruitment mode (vegetative or from seed) and to measure the apical growth of a randomly selected subset of approximately 25 aroid individuals, irrespective of species. This growth was measured by carefully indicating the position of the apical meristems using small cuts on the tree bark or plastic tags. We estimated the percentage of diffuse light (diffuse site factor; Anderson 1964) for each of these aroids by taking hemispherical photographs above the centre of the plant (Roxburgh \& Kelly 1995). We took 
the photographs early in the morning or late in the afternoon on overcast days; these were underexposed by one stop (Hale \& Edwards 2002), processed using Adobe ${ }^{\circledR}$ Photoshop ${ }^{\circledR}$ CS2 software (version 9) and analysed with the Gap Light Analyzer software program (Frazer et al. 1999).

For the directional growth study we laid out 21 transects (others than used for the recruitment and growth study) in forest adjacent to recent clearings (11 transects) and gaps caused by the recent fall of a large tree (10 transects). Tree-fall gaps were located along a $5-\mathrm{km}$ path in the mature forest, and were typically about $25 \times 10 \mathrm{~m}$ in size. Because the falling tree had destroyed most trees and shrubs, the gap-forest transition was clear and generally occurred over a distance of $2 \mathrm{~m}$ or less. All transects extended $20 \mathrm{~m}$ into the forest, in a direction perpendicular to the transition of the forest with the clearing or the tree-fall gap. Along each transect, we randomly established at least five points. At each point, we selected the nearest hemiepiphytic aroid in each of the four quadrants, following the point-centred-quarter method (Cottam \& Curtis 1956, Engeman et al. 1994). For vegetatively spreading aroids, each stem was regarded as a separate individual (ramet). The line between the apex and the last two internodes defined the directional growth of the youngest internodes (Sampaio et al. 2004).

\section{Numerical analyses}

Following protocols of Zuur et al. (2009) to simplify the models regarding random effects, we tested our hypotheses 1 and 3 to 6 applying generalized least squares (gls) and (generalized) mixed-effects models (lme, lmer).

Hypothesis 1: for each species, we modelled the arcsinetransformed (Zar 1999) proportions of seeds that had germinated after 2 mo against shade (three shade classes) and soil (two classes: mature forest soil and fallow soil) using the following model:

model $1<-$ gls(shade+soil+shade:soil, weights = varComb $($ varIdent(form $=\sim 1 \mid$ soil $)$, varIdent(form $=\sim 1 \mid$ shade $))$ )

where weights describes the heteroscedasticity structure within shade and soil classes (Pinheiro \& Bates 2000).

Hypothesis 3: we regressed the binary response flagel (flagellar shoots present or not) against habitat (in three classes: open, forest edge and mature forest), with diffuse light levels as random slope and species nested in transect as random intercept, as follows:

model $3<-$ Imer(flagel $\sim$ habitat + (diffuselight $\mid$ transect/ species), family $=$ binomial)

We tested for the significance of the habitat effect by comparing this model with one from which habitat was removed, using maximum likelihood and a chi-squared test.
Hypothesis 4: the apical growth rate (r) was calculated as:

$$
\mathrm{r}=(\mathrm{L} 2-\mathrm{L} 1) /(\mathrm{T} 2-\mathrm{T} 1)
$$

in which L1 and L2 were the stem length at the start (T1) and the end (T2) of the measurement period (Chao et al. 2008, Hoffman \& Poorter 2002, Rüger et al. 2011). A logarithmic transformation of $r$ was applied to increase the symmetry of its distribution. Logarithmic growth rate was regressed against the binary factor flagel (flagellar shoots present or not), habitat (in the three classes as indicated above) and the interaction between these two variables. Initially, diffuse light levels were included as random slope and species (nested in transect) as random intercept, while habitat was added as variance covariate. During model selection, diffuse light levels were removed, resulting into:

model $4<-\operatorname{lme}(\log (\mathrm{r}+0.1) \sim$ flagel + habitat + flagel:habitat, random $=(\sim 1 \mid$ transect/species $)$, weights $=$ varIdent $($ form $=$ $\sim 1$ (habitat))

where weights describes the heteroscedasticity structure within habitat classes (Pinheiro \& Bates 2000).

Hypothesis 5: here, the logarithmic growth rate was regressed against the binary factor flagel (flagellar shoots present or not), distance of the initial position of the aroid's apex towards the border with the open habitat, and the interaction between these two variables. Initially, diffuse light levels were included as random slope and species nested in transect as random intercept. During model selection, diffuse light levels were removed, yielding the final model as follows:

model $5<-\operatorname{lme}(\log (\mathrm{r}+0.1) \sim$ flagel + distance + flagel:distance, random $=(\sim 1 \mid$ transect $/$ species $))$

Hypothesis 6: we first calculated for each aroid the cosine of the angle between the line of directional growth and the transect direction. These cosine values were regressed against the aroid's distance (with precision of $0.5 \mathrm{~m}$ ) to the border with the clearing or tree-fall gap, the binary factor flagel (flagellar shoots present or not) and the interaction between these two variables. The aroid's distance was also included as random slope and the transect was inserted as random intercept. Initial models, which included species as random effect (nested in transect), broke down because most species occurred in few transects. Therefore the final model only included data from Philodendron ernestii. It was as follows:

model $6<-$ lme $($ cosine $\sim$ flagel + distance + flagel:distance, random $=(\sim 1 \mid$ distance/transect $))$

Regarding models 3 to 6 , spatial autocorrelation of the residuals within transects was examined using semivariograms and spline correlograms (Bjørnstad \& Falck 2001). In none of the models was it detected. All analyses were conducted using R 2.14.1, applying nlme 


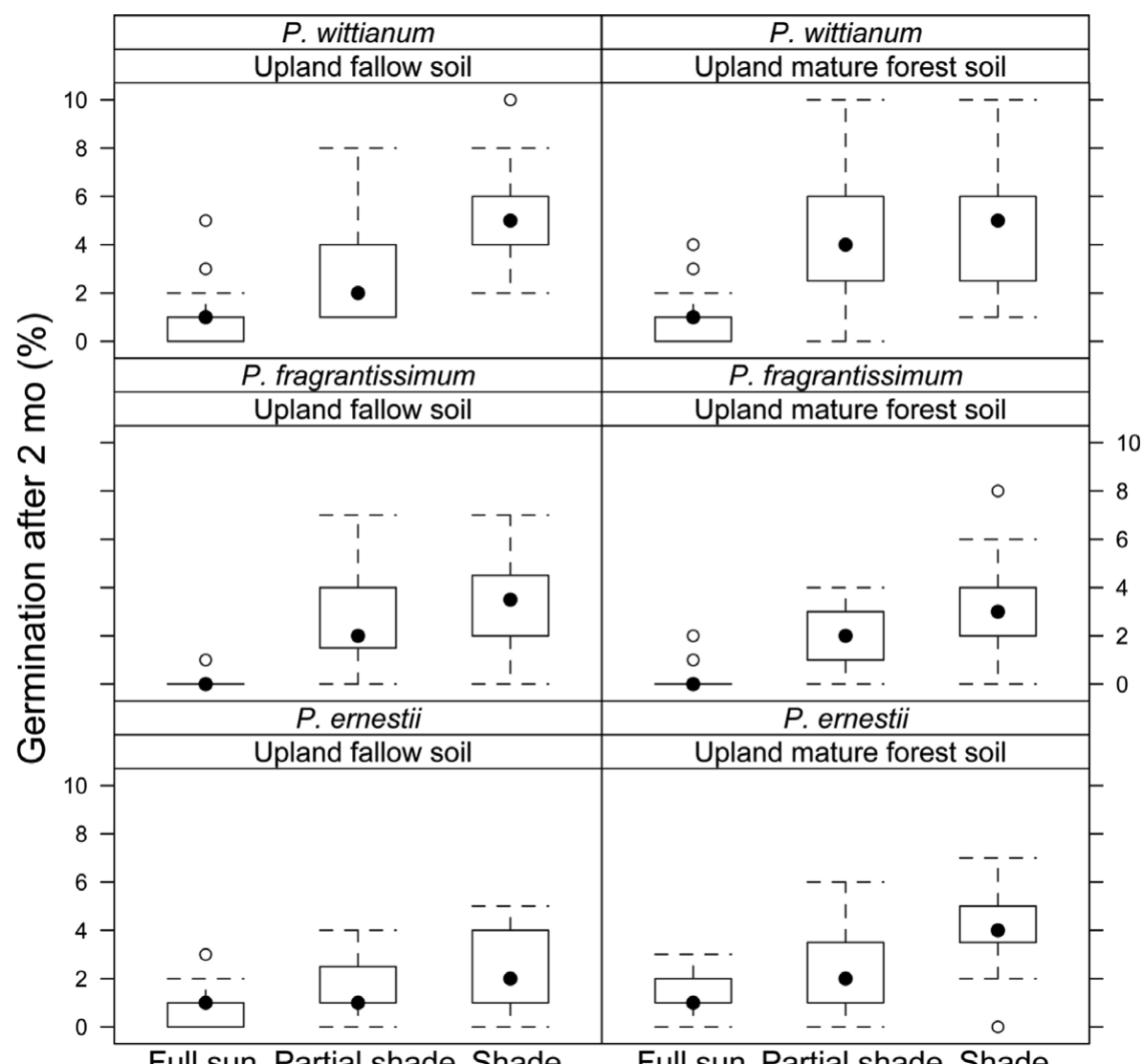

Figure 1. Box-and-whisker plots to show the proportion of seeds of three Philodendron species that germinated after 2 mo in response to three levels of shading and two classes of soil substrate, in an experiment carried out in the village of Mocagua, Colombian Amazonia. The whiskers extend from the quartiles up to 1.5 times the interquartile range.

(version 3.1-103), lme4 (version 0.999375-42), ncf (version 1.1-4) and lattice (version 0.20-10; Sarkar 2008) packages.

\section{RESULTS}

The germination experiment showed that all three aroid species germinated most successfully under conditions of low light (Figure 1, Table 1). The shading effect was highly significant for all three species. Seeds of $P$. ernestii germinated slightly better on mature-forest soils. No significant soil-shading interaction effects were found.

The cuttings from all aroid species sprouted within $6 \mathrm{wk}$. On average $7.5 \%$ of the cuttings sprouted after $6 \mathrm{wk}$, and $11.8 \%$ after $14 \mathrm{wk}(3.8 \%, 8.8 \%, 8.8 \%$, $7.5 \%$ and $8.8 \%$ after $6 \mathrm{wk}$, and $3.8 \%, 13.8 \%, 18.8 \%$, $10 \%$ and $12.5 \%$ for Philodendron elaphoglossoides, P. ernestii, P. fragrantissimum, P. heleniae and P. wittianum, respectively).

Along the monitoring transects, we recorded a total of 2133 aroid plants, represented by 41 species and six genera (see Appendix 1). Philodendron ernestii dominated
Table 1. F-values of the fixed effects in the generalized least squares model to test if light (three shade levels) or soil (two soil classes) affected the seed germination of three Philodendron species in Mocagua, Colombian Amazonia. $\mathrm{df}=$ degrees of freedom; the $\mathrm{df}$ of the denominator was 90 for $P$. ernestii, and 186 for the other two species $*=0.01 \leq \mathrm{P}<0.05$; ${ }^{* *}=0.001 \leq \mathrm{P}<0.01 ;^{* * *}=\mathrm{P}<0.001$.

\begin{tabular}{lcccc}
\hline & & \multicolumn{3}{c}{$\mathrm{F}$} \\
\cline { 3 - 5 } & Numerator df & P. ernestii & P. fragrantissimum & P. wittianum \\
\hline (Intercept) & 1 & $630^{* * *}$ & $980^{* * *}$ & $1300^{* * *}$ \\
Light & 2 & $14^{* * *}$ & $170^{* * *}$ & $87^{* * *}$ \\
Soil & 1 & $5.7^{*}$ & 0.2 & 1.7 \\
Light: soil & 2 & 0.4 & 3.0 & 1.8 \\
\hline
\end{tabular}

the aroid community with 565 records, which was more than twice the total abundance of the second most dominant species (Anthurium digitatum with 252 records). In total 25 species were found in clearings and fallows, 35 in forest edges and 32 in mature forests. Just over half (24) of the 41 species were capable of producing flagellar shoots. On average, the initial density of plants with non-flagellar shoots was five to six times higher than that of flagellar aroids (Table 2). The comparison of the mixed models with and without habitat as fixed 
Table 2. Hemiepiphytic aroid density with and without flagellar shoots (number of plants per $10 \mathrm{~m}^{2}$, mean $\pm \mathrm{SD}$ ) in three habitats in the forests near Amacayacu, Colombia. $\mathrm{N}=$ number of transects.

\begin{tabular}{lrlc}
\hline & & \multicolumn{2}{c}{ Aroid density } \\
\cline { 3 - 4 } Habitat & $\mathrm{N}$ & Non-flagellar & Flagellar \\
\hline Open & 14 & $2.60 \pm 3.01$ & $0.53 \pm 0.64$ \\
Forest edge & 14 & $8.14 \pm 4.40$ & $1.69 \pm 1.42$ \\
Mature forest & 8 & $12.4 \pm 4.20$ & $1.90 \pm 0.70$ \\
\hline
\end{tabular}

Table 3. Recruitment of hemiepiphytic aroids after 14 mo (number of plants per $10 \mathrm{~m}^{2}$, mean $\pm \mathrm{SD}$ ) in three habitats in the forests near Amacayacu, Colombia. $\mathrm{N}=$ number of transects.

\begin{tabular}{lrccc}
\hline & & \multicolumn{3}{c}{ Recruitment mode } \\
\cline { 3 - 5 } Habitat & $\mathrm{N}$ & Seedling & Vegetative & Unknown \\
\hline Open & 13 & $0.13 \pm 0.16$ & $0.15 \pm 0.12$ & $0.02 \pm 0.04$ \\
Forest edge & 13 & $0.19 \pm 0.18$ & $0.31 \pm 0.21$ & $0.01 \pm 0.02$ \\
Mature forest & 8 & $0.30 \pm 0.32$ & $0.10 \pm 0.15$ & $0.18 \pm 0.23$ \\
\hline
\end{tabular}

Table 4. Number of hemiepiphytic aroids that recruited during a period of $14 \mathrm{mo}$ in a total area of $1760 \mathrm{~m}^{2}$ in open habitats (recent clearings and fallows $<2$ y old) near Amacayacu, Colombia. AMB codes refer to collection numbers of Ana María Benavides.

\begin{tabular}{lccc}
\hline Species & Seedling & Vegetative & Unknown \\
\hline $\begin{array}{l}\text { Anthurium digitatum } \\
\text { Monstera lechleriana }\end{array}$ & 4 & & \\
Monstera sp. (AMB 4168) & & 1 & 1 \\
Philodendron aff. guttiferum & & 1 & \\
Philodendron cataniaponense & 1 & & \\
Philodendron chinchamayense & 1 & & \\
Philodendron deflexum & 1 & 15 & 1 \\
Philodendron ernestii & 10 & 1 & \\
Philodendron ornatum & 1 & 3 & \\
Philodendron sp. (AMB 1572) & & 2 & 2 \\
Syngonium sp. (AMB 1583) & 1 & 23 & 3 \\
Total & 19 & & \\
\hline
\end{tabular}

effect on the presence-absence of flagellar aroids did not yield a significant difference $\left(\chi^{2}=2.2 ; \mathrm{P}=0.33\right)$. Hence, evidence that the probability to record a flagellar aroid depended on habitat could not be detected.

In the 14-mo monitoring period, aroid recruitment into clearings and fallows was surprisingly low (mean of 0.3 plants per $10 \mathrm{~m}^{2}$; Table 3), especially in comparison to the initial density of aroid plants (mean of 3.1 plants per $10 \mathrm{~m}^{2}$; Table 2). A similar number of open-habitat recruits originated by seed dispersal or through vegetative reproduction (Table 4). Most of these recruits belonged to Philodendron ernestii.

We used 632 aroids to monitor apical growth (see Appendix 1). These plants belonged to 33 species; Philodendron ernestii was most abundant (161 stems). After $14 \mathrm{mo}$, the maximum stem growth was $888 \mathrm{~cm}$. Over a 2-mo period, the fastest aroid growth was $106 \mathrm{~cm} \mathrm{mo}^{-1}$ in open habitats, $97 \mathrm{~cm} \mathrm{mo}^{-1}$ in forest edges, and $98 \mathrm{~cm} \mathrm{mo}^{-1}$ in mature forests. A total of 53
Table 5. Apical growth of hemiepiphytic aroids $\left(\mathrm{cm} \mathrm{mo}^{-1}\right.$, mean \pm SD (N)), measured after 14 mo in three habitats in the forests near Amacayacu, Colombia. $\mathrm{N}=$ number of aroid plants.

\begin{tabular}{llc}
\hline Habitat & Non-flagellar aroids & Flagellar aroids \\
\hline Open & $6.1 \pm 11.6(82)$ & $17.4 \pm 18.8(31)$ \\
Forest edge & $3.6 \pm 7.0(199)$ & $7.0 \pm 8.6(75)$ \\
Mature forest & $1.4 \pm 3.4(201)$ & $4.4 \pm 7.7(44)$ \\
\hline
\end{tabular}

Table 6. F-values of the fixed effects in the (generalized) mixed-effects models to test three hypotheses of aroid growth in open habitats and adjacent forests near Amacayacu, Colombian Amazonia, as follows: if aroids, and especially flagellar aroids, grow faster in open habitats than in closed forests (model4); if they show faster growth in forest edges when occurring closer to open habitats (model5); and if they show directional growth towards the open habitat in such conditions (model6); $\mathrm{df}=$ degrees of freedom; ${ }^{*}=0.01 \leq \mathrm{P}<0.05$; $^{* *}=0.001 \leq$ $\mathrm{P}<0.01 ;^{* * *}=\mathrm{P}<0.001$.

\begin{tabular}{lccc}
\hline & Numerator df & Denominator df & $\mathrm{F}$ \\
\hline Model4 & & & \\
(Intercept) & 1 & 446 & 1.7 \\
Flagel & 1 & 446 & $40^{* * *}$ \\
Habitat & 2 & 446 & $6.5^{* *}$ \\
Flagel : habitat & 2 & & 0.5 \\
Model5 & & 159 & \\
(Intercept) & 1 & 159 & 1.9 \\
Flagel & 1 & 159 & 1.5 \\
Distance & 1 & 159 & 0.2 \\
Flagel : distance & 1 & 95 & \\
Model6 & & 95 & 3.1 \\
(Intercept) & 1 & 95 & 0.3 \\
Flagel & 1 & 95 & 0.2 \\
Distance & 1 & & 1.1 \\
Flagel : distance & 1 & & \\
\hline
\end{tabular}

stems ( $8.4 \%$ of the stems, of which 27 were flagellar) grew at a rate $>2 \mathrm{~m}$ per $14 \mathrm{mo}$, and 27 stems (of which 12 were flagellar) grew at a rate $>3 \mathrm{~m}$ per $14 \mathrm{mo}$. At the start of the growth measurements, the stem length of the aroids was $117 \pm 178 \mathrm{~cm}$ in open habitats, $182 \pm 305$ $\mathrm{cm}$ in forest edges and $141 \pm 341 \mathrm{~cm}$ in mature forests (mean $\pm \mathrm{SD}$ ). The maximum stem length was $32.7 \mathrm{~m}$.

Growth rate was fastest in open habitats and slowest in mature forests (Tables 5, 6). Also, flagellar aroids grew faster than non-flagellar aroids (Tables 5, 6), but the interaction effect between habitat and the binary factor flagel was not significant. Restricting the analyses to edges, again the apical growth of flagellar aroids was faster than that of non-flagellar aroids but it did not depend on distance to the open habitat (Table 6).

The mixed-effects modelling of directional growth was conducted on the basis of 119 plants of Philodendron ernestii, which occurred in 21 transects. In the forest edges, the distance towards the open habitat or the presence-absence of flagellar shoots did not show a detectable influence on the direction of apical growth (Table 6). 


\section{DISCUSSION}

The clearings and fallows along the transects that were established to monitor aroid recruitment contained almost half of all aroid species in the area (Benavides et al. 2006). Nevertheless, aroid recruitment into these open habitats was low (only $10 \%$ of the initial density after $14 \mathrm{mo}$ ). Also, a substantial number of aroids were already present in the clearing or fallows before we started our monitoring. Whether these aroids originated from seed or from surviving adults, or fragments thereof, remains elusive; we were unable to document the recruitment mode at the initial creation of the clearings in situ. However, as all three aroid species that we tested exhibited a poor germination under high-light conditions, we speculate that a substantial part of the early aroid gap occupants originated from aroid stem fragments. Indeed, the sprouting experiment showed that, on average, more than $10 \%$ of aroid stem cuttings sprouted after $14 \mathrm{wk}$. Despite the low recruitment (in $14 \mathrm{mo}$ ), our results further indicated that a similar number of aroids recruited open habitats vegetatively (sprouting) or through seed dispersal. Other studies showed that fragment regeneration might even prevail over seed recruitment (Lasso et al. 2009). Fragments may have a similar or higher survival than seedlings and higher growth rates than saplings (Dietze \& Clark 2008, Khan et al. 1986). Our recruitment monitoring took place in man-made clearings and fallows where slash-and-burn practices and weeding may have removed previously established aroid seedlings and adult aroid stem fragments. In natural tree-fall gaps, recruitment and survival of aroid seedlings and sprouted fragments might be substantially higher.

For aroids, analogous to the lateral spread of lianas (Peñalosa 1984, Putz 1984), flagellar shoots might facilitate the lateral invasion of open space, such as manmade forest clearings or tree-fall gaps (Andrade \& Mayo $1998,2000)$. Indeed, the apical growth of flagellar aroids in forest edges (mean of $98 \mathrm{~cm}$ per $14 \mathrm{mo}$ ) would permit such plants to reach a clearing or tree-fall gap within a few years. We found $4.2 \%$ of the aroid stems showing a 14-mo growth of $\geq 3 \mathrm{~m}$. Up to a growth of $12 \mathrm{~m} \mathrm{y}^{-1}$ seems achievable if the growth rates recorded over 2 mo were to be sustained for $1 \mathrm{y}$. However, our transect studies failed to supply other evidence to support the lateralinvasion hypothesis. Generally, flagellar aroids were less common than non-flagellar aroids, and in open habitats the chance to encounter an aroid with flagellar shoots was just as low as in forest habitats. No proof was found that the growth rate of flagellar aroids relative to that of non-flagellar aroids depended on habitat, nor did we find any effect of distance towards the open habitat on growth or growth direction of aroids in forest edges. Flagellar aroids grew faster than non-flagellar aroids and growth of aroids in general was faster in open habitats (presumably stimulated by higher light availability). Both these phenomena may well contribute to the fast aroid colonization in forest clearings, but their detection does not allow conclusions about the arrival mechanism.

In conclusion, the colonization of open habitats such as clearings and tree-fall gaps in Amazonian rain forest by hemiepiphytic aroids appears to be driven by a high post-disturbance survival of adult plants, or fragments thereof. New recruitment, especially from flagellar aroids may also occur. Further research is necessary to assess what triggers the formation of flagellar shoots in aroids, and to assess the survival and sprouting capacity of adult aroids directly after tree-fall events and clearings of the forest.

\section{ACKNOWLEDGEMENTS}

We thank Amacayacu National Park and the communities of Mocagua and Palmeras. We also thank A. C. Kuchta, Y. Campiño, L. V. Londoño and C. J. Benavides for help with fieldwork, and J. van Arkel and F. van Dunné for the hemispherical photograph processing. A. M. Benavides received subsidies from the SchureBeijerinck-Popping fund, the Alberta Mennega fund, the AUV fund and Programme Alban. J. Wolf was supported by The Stichting Het Kronendak.

\section{LITERATURE CITED}

ANDERSON, M. C. 1964. Studies in the woodland light climate. The photographic computation of light conditions. Journal of Ecology 52:27-41.

ANDRADE, I. M. \& MAYO, S. J. 1998. Dynamic shoot morphology in Monstera adansonii Schott var. klotzschiana (Schott) Madison (Araceae). Kew Bulletin 53:399-417.

ANDRADE, I. M. \& MAYO, S. J. 2000. Dynamic shoot morphology in root-climbing Araceae: Philodendron rudgeanum Schott and Ph. fragrantissimum (Hook.) G.Don. Feddes Repertorium 111:295314.

BALCÁZAR-VARGAS, M. P., PEÑUELA-MORA, M. C., VAN ANDEL, T. R. \& ZUIDEMA, P. A. 2012. The quest for a suitable host: size distributions of host trees and secondary hemiepiphytes search strategy. Biotropica 22:19-26.

BAZZAZ, F. A. \& PICKETT, S. T. A. 1980. Physiological ecology of tropical succession: a comparative review. Annual Review of Ecology, Evolution, and Systematics 11:287-310.

BENAVIDES, A., WOLF, J. H. D. \& DUIVENVOORDEN, J. F. 2006. Recovery and succession of epiphytes in upper Amazonian fallows. Journal of Tropical Ecology 22:705-717.

BENAVIDES, A., VASCO, A., DUQUE, A. \& DUIVENVOORDEN, J. F. 2011. Association of vascular epiphytes with landscape units and phorophytes in humid lowland forests of Colombian Amazonia. Journal of Tropical Ecology 27:223-237. 
BJØRNSTAD, O. N. \& FALCK, W. 2001. Nonparametric spatial covariance functions: estimation and testing. Environmental and Ecological Statistics 8:53-70.

CHAO, K., PHILLIPS, O. L., GLOOR, E., MONTEAGUDO, A., TORRES-LEZAMA, A. \& VÁSQUEZ M., R. 2008. Growth and wood density predict tree mortality in Amazon forests. Journal of Ecology 96:281-292.

CHAZDON, R. L. 1986. Light variation and carbon gain in rain-forest understory palms. Journal of Ecology 74:995-1012.

CLARK, D., PALMER, M. \& CLARK, D. 1999. Edaphic factors and the landscape-scale distributions of tropical rain forest trees. Ecology 80:2662-2675.

COTTAM, G. \& CURTIS, J. 1956. The use of distance measures in phytosociological sampling. Ecology 37:451-460.

CROAT, T. 1992. Species diversity of Araceae in Colombia: a preliminary survey. Annals of the Missouri Botanical Garden 79:17-28.

DALLING, J. W., SWAINE, M. D. \& GARWOOD, N. C. 1998. Dispersal patterns and seed bank dynamics of pioneer trees in moist tropical forest. Ecology 79:564-578.

DENSLOW, J. S. 1987. Tropical rainforest gaps and tree species diversity. Annual Review of Ecology, Evolution, and Systematics 18:431451.

DIETZE, M. C. \& CLARK, J. S. 2008. Changing the gap dynamics paradigm: vegetative regeneration control on forest response to disturbance. Ecological Monographs 78:331-347.

ENGEMAN, R. M., SUGIHARA, R. T., PANK, L. F. \&DUSENBERRY, W.E. 1994. A comparison of plotless density estimators using Monte Carlo simulation. Ecology 75:1769-1779.

FRAZER, G. W., CANHAM, C. D. \& LERTZMAN, K. P. 1999. Gap Light Analyzer (GLA): imaging software to extract canopy structure and gap light transmission indices from true-colour fisheye photographs, users' manual and program documentation. Version 2.0. Simon Fraser University, Burnaby. 36 pp.

GENTRY, A. H. \& DODSON, C. H. 1987. Diversity and biogeography of neotropical vascular epiphytes. Annals of the Missouri Botanical Garden 74:205-233.

GRUBB, P. J. 1977. The maintenance of species-richness in plant communities: the importance of the regeneration niche. Biological Reviews of the Cambridge Philosophical Society 52:107145.

HALE, S. E. \& EDWARDS, C. 2002. Comparison of film and digital hemispherical photography across a wide range of canopy densities. Agricultural and Forest Meteorology 112:51-56.

HOFFMAN, W. A. \& POORTER, H. 2002. Avoiding bias in calculations of relative growth rate. Annals of Botany 80:37-42.

KHAN, M., RAI, J. \& TRIPATHI, R. 1986. Regeneration and survival of tree seedlings and sprouts in tropical deciduous and sub-tropical forests of Meghalaya, India. Forest Ecology and Management 14:293304.
LASSO, E., ENGELBRECHT, B. M. \& DALLING, J. W. 2009. When sex is not enough: ecological correlates of resprouting capacity in congeneric tropical forest shrubs. Oecologia 161:43-56.

LEIMBECK, R. M. \& BALSLEV, H. 2001. Species richness and abundance of epiphytic Araceae on adjacent floodplain and upland forest in Amazonian Ecuador. Biodiversity and Conservation 10:15791593.

NIEDER, J., ENGWALD, S., KLAWUN, M. \& BARTHLOTT, W. 2000. Spatial distribution of vascular epiphytes (including hemiepiphytes) in a lowland Amazonian rain forest (Surumoni crane plot) of southern Venezuela. Biotropica 32:385-396.

PEÑALOSA, J. 1984. Basal branching and vegetative spread in two tropical rain-forest lianas. Biotropica 16:1-9.

PINHEIRO, J. C. \& BATES, D. M. 2000. Mixed-effects models in $S$ and S-Plus. Springer, New York. 528 pp.

PUTZ, F. 1984. The natural-history of lianas on Barro-Colorado Island, Panama. Ecology 65:1713-1724.

RAY, T. S. 1992. Foraging behavior in tropical herbaceous climbers (Araceae). Journal of Ecology 80:189-203.

ROXBURGH, J. \& KELLY, D. 1995. Uses and limitations of hemispherical photography for estimating forest light environments. New Zealand Journal of Ecology 19:213-217.

RUDAS, A. \& PRIETO, A. 2005. Flórula del Parque Nacional Natural Amacayacu Amazonas, Colombia. Missouri Botanical Garden Press, St Louis. $680 \mathrm{pp}$.

RÜGER, N., BERGER, U., HUBBELL, S. P., VIEILLEDENT, G. \& CONDIT, R. 2011. Growth strategies of tropical tree species: disentangling light and size effects. PLOS ONE 6:e25330.

SAMPAIO, M. C., ARAUJO, T. F., SCARANO, F. R. \& STUEFER, J. F. 2004. Directional growth of a clonal bromeliad species in response to spatial habitat heterogeneity. Evolutionary Ecology 18:429-442.

SARKAR,D. 2008. Lattice: multivariate data visualization with R. Springer, New York. 268 pp.

SCHNITZER, S. A. \& CARSON, W. P. 2001. Treefall gaps and the maintenance of species diversity in a tropical forest. Ecology 82:913919.

SCHNITZER, S. A., DALLING, J. W. \& CARSON, W. P. 2000. The impact of lianas on tree regeneration in tropical forest canopy gaps: evidence for an alternative pathway of gap-phase regeneration. Journal of Ecology 88:655-666.

SCHNITZER, S. A., MASCARO, J. \& CARSON, W.P. 2008. Treefall gaps and the maintenance of species diversity in tropical forests. Pp. 196209 in Carson, W. P. \& Schnitzer, S. A. (eds.). Forest community ecology. Wiley-Blackwell, Oxford.

ZAR, J. H. 1999. Biostatistical analysis. (Fourth edition). Prentice-Hall, Upper Saddle River. 663 pp.

ZUUR, A. F., IENO, E., WALKER, N. J., SAVALIEV, A. A. \& SMITH, G. M. 2009. Mixed effects models and extensions in ecology with R. Springer, New York. 574 pp. 
Appendix 1. Hemiepiphytic aroid species found in open habitats (recent forest clearings and fallows $<2 \mathrm{y}$ old), forest edges adjacent to these open habitats, and mature upland forests at least $200 \mathrm{~m}$ away from these open habitats, in Amacayacu National Park, Colombian Amazonia. The values represent numbers of individuals. AMB codes refer to collection numbers of Ana María Benavides.

\begin{tabular}{|c|c|c|c|c|c|}
\hline & Open habitat & Forest edge & Mature forest & Flagellar plants & Growth recordings \\
\hline Anthurium clavigerum Poepp. & 3 & 1 & & & 1 \\
\hline A. digitatum (Jacq.) Schott & 77 & 139 & 36 & 6 & 58 \\
\hline A. eminens Schott & 0 & 4 & 11 & 1 & 4 \\
\hline A. охусагрит Poepp. & 0 & 1 & 1 & & 1 \\
\hline A. pentaphyllum (Aubl.) G. Don & 1 & 2 & 2 & & 1 \\
\hline A. polyschistum R.E. Schultes \& Idrobo & 2 & 14 & & & 3 \\
\hline Heteropsis tenuispadix G.S. Bunting & 0 & 1 & 1 & & 1 \\
\hline Monstera aff. obliqua Miq & 0 & 0 & 5 & 2 & \\
\hline M. gracilis Engl. & 4 & 20 & & 1 & 12 \\
\hline M. lechleriana Schott & 1 & 0 & & & 1 \\
\hline M. obliqua Miq & 2 & 22 & 21 & 2 & 13 \\
\hline M. spruceana (Schott) Engl. & 8 & 55 & 42 & 16 & 30 \\
\hline M. sp. (AMB 4168) & 2 & 19 & 9 & 4 & 9 \\
\hline M. sp. (AMB 4177) & 7 & 29 & 13 & 5 & 12 \\
\hline Philodendron aff. exile G.S. Bunting & 0 & 9 & & 2 & \\
\hline$P$. aff. guttiferum Kunth & 10 & 58 & 28 & 17 & 39 \\
\hline P. asplundii Croat & 0 & 10 & 4 & & 4 \\
\hline P. cataniaponense G.S. Bunting & 10 & 2 & 1 & & 4 \\
\hline P. chinchamayense Engl. & 1 & 1 & 8 & & 10 \\
\hline P. deflexum Poepp. ex Schott & 5 & 8 & 3 & & 6 \\
\hline P. elaphoglossoides Schott & 2 & 4 & & 1 & 1 \\
\hline P. ernestii Engl. & 216 & 293 & 56 & 150 & 161 \\
\hline P. fragantissimum (Hook.) G. Don & 17 & 69 & 68 & 33 & 45 \\
\hline P. grandifolium (Jacq.) Schott & 6 & 12 & 4 & 2 & 4 \\
\hline P. hederaceum (Jacq.) Schott & 0 & 7 & 2 & 1 & 5 \\
\hline P. heleniae Croat & 0 & 1 & & & \\
\hline P. hylaeae G.S. Bunting & 0 & 0 & 1 & & \\
\hline P. insigne Schott & 0 & 0 & 1 & & 1 \\
\hline P. linnaei Kunth & 4 & 15 & 1 & 5 & 4 \\
\hline P. mawarinumae G.S. Bunting & 0 & 22 & 76 & 20 & 42 \\
\hline P. micranthum Poepp. ex Schott & 0 & 2 & & & 2 \\
\hline P. ornatum Schott & 4 & 0 & & & \\
\hline P. panduriforme (Kunth) Kunth & 0 & 0 & 1 & & \\
\hline$P$. sp. (juvenile stage) & 0 & 3 & 1 & 1 & \\
\hline P. sp. (AMB 1572) & 41 & 128 & 54 & 32 & 66 \\
\hline P. sp. (AMB 2075) & 0 & 5 & 18 & 2 & 8 \\
\hline P. uleanum Engl. & 0 & 1 & 2 & & \\
\hline P. wittianum Engl. & 1 & 10 & 23 & 7 & 12 \\
\hline P. wurdackii G.S. Bunting & 18 & 36 & 4 & 14 & 11 \\
\hline Rhodospatha sp. (AMB 4160) & 1 & 33 & 22 & 8 & 27 \\
\hline Syngonium sp. (AMB 1583) & 39 & 48 & 48 & 24 & 34 \\
\hline
\end{tabular}

